Working Paper 97-6 / Document de travail 97-6

Lagging Productivity Growth in the Service Sector: Mismeasurement, Mismanagement or Misinformation?

by

Dinah Maclean

Bank of Canada Banque du Canada 
ISSN 1192-5434

ISBN 0-662-25568-2

Printed in Canada on recycled paper 
Bank of Canada Working Paper 97-6

\title{
Lagging Productivity Growth in the Service Sector: Mismeasurement, Mismanagement or Misinformation?
}

\author{
Dinah Maclean \\ Research Department \\ Bank of Canada \\ dmaclean@bank-banque-canada.ca
}

March 1997 


\section{Acknowledgments}

While many people provided useful comments and advice, I would like to thank in particular Allan Crawford, Irene Ip, David Longworth, Gerald Stuber and Michael Denny. I am also very grateful to those people at Statistics Canada who took considerable time to explain aspects of their methodology and provided valuable comments. 


\begin{abstract}
While the service sector has been growing rapidly as a share of total output, aggregate productivity growth has generally lagged behind that of the goods sector. In this report, the author assesses a range of explanations for lagging service sector productivity growth. Measurement problems appear to be greater in services than in goods, and a detailed analysis of output measurement in the three service industries experiencing the lowest productivity growth suggests that underestimation is likely significant in finance, insurance and real estate, in community, business and personal services, and in trade. A lower level of competition in services compared with goods may also have affected productivity growth, though this impact is very hard to quantify. Explanations based on the service sector's relatively greater investment in new technology, however, are found to account at best for lagging productivity growth only in the last decade. Finally, the hypothesis that service industries are incapable of high productivity growth because of their labour-intensive nature is shown to be inapplicable to much of the service sector. The report concludes by considering which service industries are showing the greatest growth. It is found that much of the increased service-sector output has been in areas that have shown relatively strong productivity growth, or where problems of measurement are particularly severe. Moreover, there is considerable potential for greater productivity growth in areas that may have shown slower productivity increases in the past, because of such factors as technological change and ongoing adjustments to past deregulation.
\end{abstract}

\title{
Résumé
}

La part de la production totale revenant au secteur des services s'est accrue rapidement, mais la croissance de la productivité globale s'est généralement essoufflée dans ce secteur par rapport à celui des biens. L'auteure examine un certain nombre d'éléments d'explication de ce ralentissement de la productivité. Les problèmes de mesure paraissent plus importants dans le secteur des services, et une analyse approfondie du mode de détermination de la production semble indiquer que celle-ci est probablement fortement sous-estimée dans les trois industries de services où la croissance de la productivité est le plus faible - soit les finances, les assurances et les affaires immobilières, les services socio-culturels, commerciaux et personnels, et le commerce. La plus faible concurrence qui existe dans le secteur des services peut également avoir influé sur la croissance de la productivité, mais cette incidence est difficile à mesurer. Les explications fondées sur le fait que le secteur des services investit relativement plus dans les technologies nouvelles ne s'appliquent au mieux qu'à la dernière décennie. Enfin, l'hypothèse selon laquelle les industries de services ne peuvent réaliser d'importants gains de productivité parce qu'elles utilisent une main-d'oeuvre nombreuse ne se vérifie pas pour la majeure partie de ce secteur. Pour conclure, l'auteure cherche à déterminer quelles sont les industries de services qui connaissent la croissance la plus forte. Elle constate que l'augmentation de la production dans le secteur des services a été surtout enregistrée dans des industries où la croissance de la productivité a été assez robuste ou qui présentent des problèmes de mesure particulièrement importants. Qui plus est, en raison entre autres des innovations technologiques et des changements en cours induits par la déréglementation, il y a de fortes chances pour que la productivité s'accélère dans certaines industries où sa croissance a été plutôt lente par le passé. 


\section{Table of Contents}

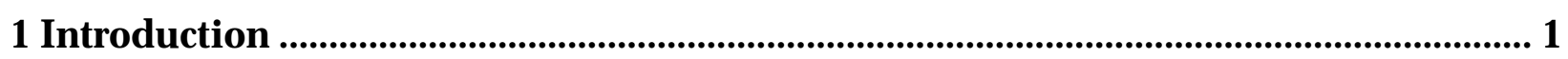

2 Productivity Growth in the Service Sector: Some Stylized Facts ................................... 3

2.1 What Is a Service? ............................................................................................................... 3

2.2 Productivity Data .................................................................................................................... 3

2.3 Productivity Growth in the Goods and Service Sectors............................................. 3

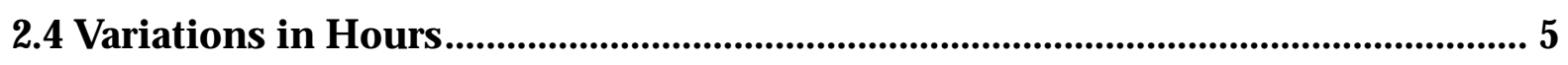

2.5 Productivity Growth by Industry …………………......................................................... 5

2.6 Multifactor Productivity ..................................................................................................... 7

2.7 An Alternative Measure of Productivity .......................................................................... 9

2.8 Summary ............................................................................................................................ 9

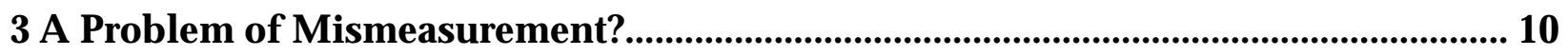

3.1 The Problem ......................................................................................................................... 10

3.2 Finance, Insurance and Real Estate .......................................................................... 11

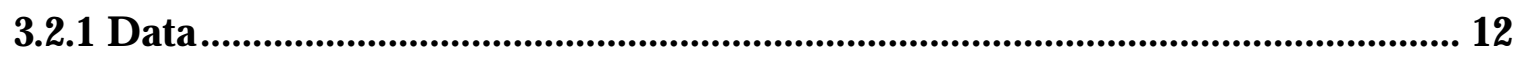

3.2.2 Areas of Possible Downward Bias and Uncertainty ......................................... 13

3.3 Community, Business and Personal Services................................................................. 15

3.4 Retail and Wholesale Trade ............................................................................................ 17

3.5 Conclusion and Implications........................................................................................... 19

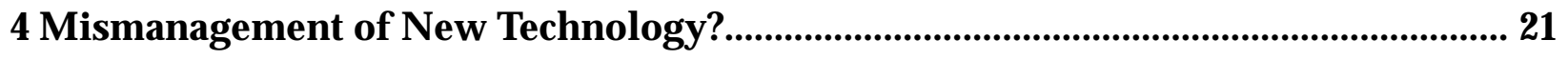

5 Lack of Competition? ....................................................................................................... 24

6 An Innate Feature of the Service Sector?......................................................................... 26

7 Conclusion: the Macroeconomic Consequences................................................................... 28

Bibliography ……...................................................................................................................... 30

Appendix 1: $\quad$ Calculation of Labour Productivity ........................................................... 33

Appendix 2: $\quad$ The Measurement of FIRE, CBPS and Trade........................................ 36 


\section{Introduction}

The rapid growth in the production of services has been a feature of most industrialized countries in the post-war period. In Canada, services now account for three-quarters of total employment, and more than two-thirds of total output. ${ }^{1}$ The growth has been fuelled both by increased demand from consumers due to rising incomes and changing tastes, and by demand for service inputs from the goods sector. In addition, technological change has transformed many services, such as banking and medical research, and has led to the growth of entirely new service activities, such as the software industry.

At the same time, aggregate productivity growth in the service sector has generally lagged behind that of the goods sector, leading to concerns that, as the size of the service sector increases, total economy-wide productivity growth will be reduced. Some envision an ever-increasing amount of resources being devoted to low-productivity activities, leading inexorably to increasing costs, lower growth and inflationary pressures. ${ }^{2}$ Certainly, lower overall productivity growth would result in lower growth in potential output or, in other words, would lead to slower increases in the level of output that the economy can sustain without raising inflation. It would also limit rates of sustainable, aggregate real wage increases.

This paper will attempt to demonstrate that concerns about lagging productivity growth in the service sector undermining our standard of living are largely overplayed. To set the context for the discussion, Section 2 explains the data sources and reviews the stylized facts. In particular, it is shown that while it is true that aggregate service-sector productivity growth has lagged goods-sector productivity growth, there is a broad range of performances among the various service industries, with some outperforming the goods sector. Sections 3 to 6 then consider the main reasons put forward to explain lagging service-sector productivity growth: Section 3 considers measurement difficulties, with particular focus on finance, insurance and real estate (FIRE), community, business and personal services (CBPS), and trade; Section 4 discusses issues associated with investment in new technology; Section 5 examines the general idea that the lower level of competition in the service sector has reduced productivity growth; and Section 6 considers the extent to which services can be categorized as incapable of high productivity growth. Although no attempt is made to quantify the effects of the different explanations of lagging service-sector productivity growth, general assessments are made about their validity. In particular, it is found that measurement errors are likely important for those service industries that have the lowest productivity growth, and that the idea of services being incapable of strong productivity growth is invalid for most of the service sector.

The final section draws some implications for the future growth of total output. In particular, it is shown that, at most, less than one-half of the increased output share of

1. For good descriptions of the growth in the service sector in Canada see Chand (1983), Grubel and Walker (1989), and Stuber (1990).

2. These are the conclusions arising from the unbalanced growth models. See, for example, Baumol (1967) and Fuchs (1968). 
commercial services has been in those industries that have experienced lagging productivity growth, and much of this was in areas where underestimation is likely severe. Given that much of the growth has been in areas where productivity increases have been relatively strong, and will likely continue to be so, concerns that future growth in productivity and potential output will be compromised by service-sector increases do not appear valid. 


\section{Productivity Growth in the Service Sector: Some Stylized Facts}

While the fact that service-sector productivity growth has generally lagged behind that of the goods sector is widely accepted, the details of recent productivity movements are less well known. This section considers, therefore, the size of the disparity and how it has changed over time, and whether lower-than-average productivity growth is widespread across the service sector or is confined to specific service industries.

\subsection{What Is a Service?}

For the purposes of this project, the definition of services used is that given in the Standard Industries Classification used by Statistics Canada. ${ }^{3}$ According to this, the service sector broadly encompasses those industries that do not produce tangible output: transportation and storage; communications; wholesale and retail trade; finance, insurance and real estate (FIRE); and community, business and personal services (CBPS). While government is also generally included as a service, measures of output per person are not available for this and other non-commercial services. ${ }^{4}$ This paper, therefore, considers productivity growth only in the commercial goods and service sectors.

\subsection{Productivity Data}

At the industry level, Statistics Canada publishes annual indexes of output per person and output per person-hour. ${ }^{5}$ These are partial measures of productivity, since they take into account only labour inputs. Statistics Canada also calculates measures of multifactor productivity by industry. Indexes of value-added multifactor productivity are only published at the economy-wide level and for manufacturing. Measures of gross output multifactor productivity, however, are available by industry. ${ }^{6}$

\subsection{Productivity Growth in the Goods and Service Sectors}

For the period 1962-94, mean productivity growth (per person-hour) in the goods sector was almost double that in the service sector: 3.0 per cent for goods compared to 1.6 per cent for services. This can be seen in Figure 1, which shows the log of the index of output per person-hour for the period 1960-94.

3. For discussions on the nature and definition of services see Hill (1977) and Grubel and Walker (1989, 27-34).

4. The calculation of output of the non-commercial sector is generally based on labour inputs, with productivity growth assumed to be zero.

5. Published in Statistics Canada, Aggregate Productivity Measures 1993, Catalogue 15-204E, Annual. The measure of output used in the annual productivity indexes is, up to 1991, the input-output measure of GDP at factor cost. For more recent years, when input-output measures are not available, output is estimated using the monthly measure of GDP at factor cost. Labour inputs are based on data from the Labour Force Survey (LFS), the Survey of Employment, Payrolls and Hours (SEPH) and specific industry surveys.

6. The gross output measure of multifactor productivity is based on the aggregate volume of all goods and/or services produced and work done by the industry. The sum of the gross outputs of all industries is greater than final sales since it includes all goods and services bought by other industries and used as intermediate inputs in the production of other goods and services. Thus for aggregate groups such as total goods and total services, value-added measures should be used. For more information on definitions see Statistics Canada, 1996, Aggregate Productivity Measures, Cat 15-204E. 


\section{FIGURE 1 Productivity in Goods and Services 1960-94}

\section{(Annual Index of Output per Person-Hour, 1960=100)}

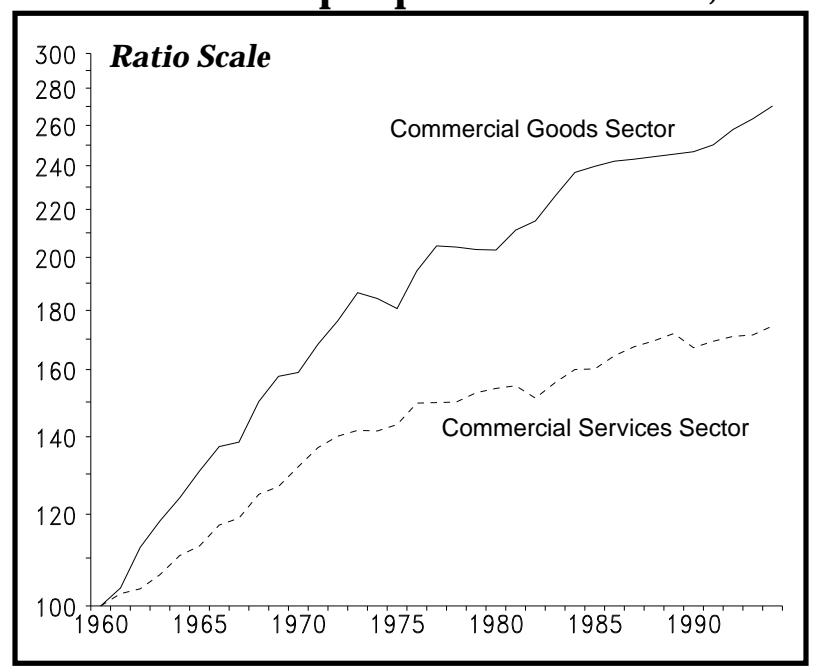

The disparity in productivity growth between the two sectors was greatest in the 1960s and early 1970s, and has diminished somewhat in more recent years. The last decade has shown the narrowest gap between the two, even including 1982 and 1990 when servicesector productivity fell sharply. The narrowing of the difference, however, was due to a reduction in the rate of productivity growth in the goods sector, not to an increase in productivity growth for services.

As well as different trends, the goods and service sectors have shown quite different patterns of productivity growth over the last two cycles. The service sector experienced substantial falls in productivity in 1982 and 1990, while goods-sector productivity grew. The goods sector, however, experienced weaker productivity growth than services at the peak of the cycles (1978-80 and 1988-89). The sharp declines in service-sector productivity during downturns were due to greater stability of employment in services relative to goods. This can be seen in Figure 2, which shows output, employment and productivity growth in both services and goods. The falls in output for the goods sector in 1982 and 1991 were sharper than the declines in service-sector output, but they were accompanied by even larger declines in employment. In the case of services, however, employment declines were more moderate than output declines.

Greater employment stability in the service sector is consistent with findings that wages in services, as measured by the index of fixed-weight average hourly earnings, show greater cyclical variation. Firms in the service sector have more flexibility, therefore, to moderate their labour costs. Factors such as the lower rate of unionization ${ }^{7}$ and a greater reliance on sales-related commissions likely contribute to this increased flexibility.

7. For example, McLaughlin (1994) found in a study of U.S. panel data that wage cuts were less frequent among unionized workers. 
FIGURE $2 \quad$ Output and Employment Growth

Annual Percentage Change

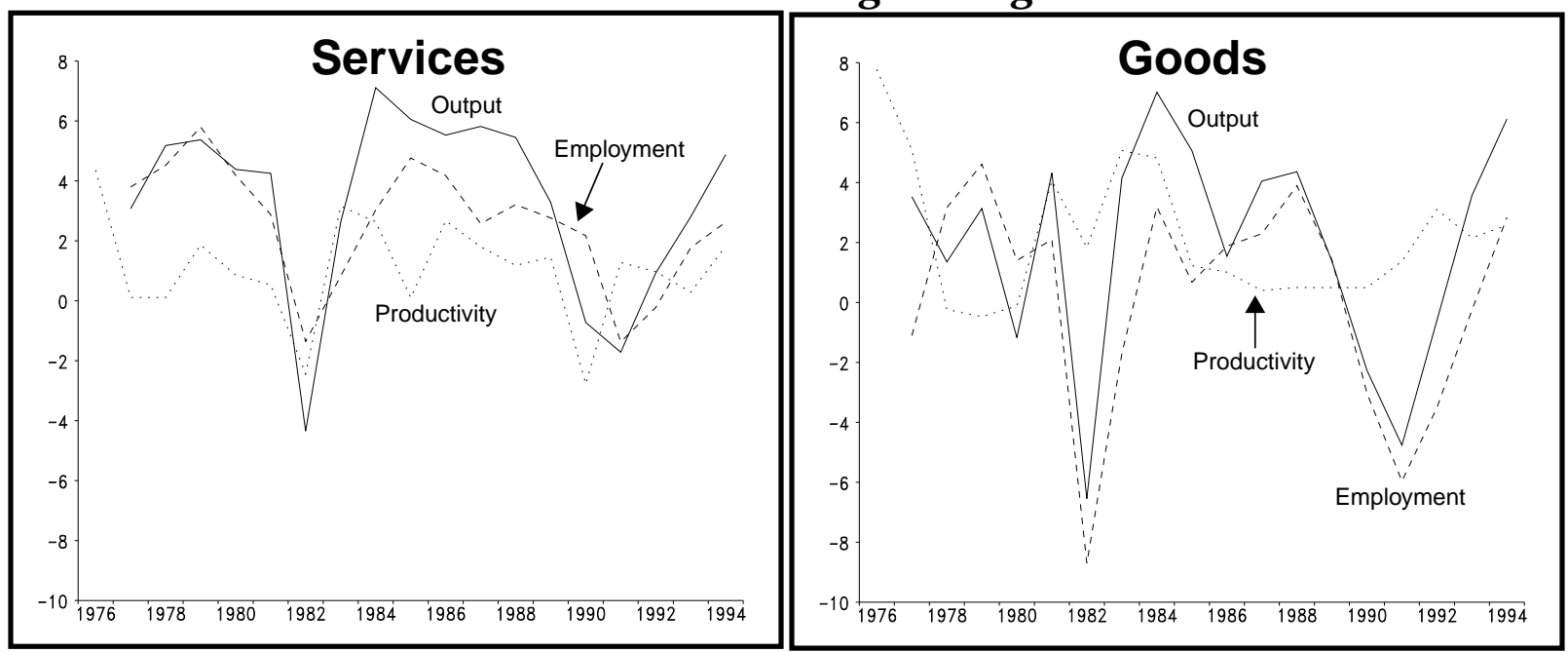

\subsection{Variations in Hours}

The disparity between productivity growth in goods and services is wider if hours are not taken into account, since average weekly hours have fallen more rapidly in the service sector. Productivity growth in both goods and services is lower when calculated using output per person. Mean growth from 1962 to 1993 falls to 2.7 and 1.1 per cent for goods and services respectively. This is consistent with the decline in total average hours worked that occurred over the study period. Moreover, the differences are greater for the earliest period (1962-71), a time when hours were declining more rapidly. The absolute difference between productivity growth in services and goods is slightly greater using output per person rather than output per person-hour, ${ }^{8}$ suggesting that hours have fallen more in the service industries. Again, this is in line with the higher incidence of part-time work in the service sector. Thus it is important to include hours worked in any analysis of productivity; otherwise differences between the sectors will be exaggerated.

\subsection{Productivity Growth by Industry}

It is very clear from industry data ${ }^{9}$ that not all services show lagging productivity growth. This can be seen in Table 1 and Figure 3, which show growth in output per person-hour. The communications sector recorded the highest average productivity growth of any industry for which data are published. Productivity growth in transportation and storage was close to the goods-sector average over the period 1962-94. Productivity growth in wholesale and retail trade was below the average for the goods sector over the study period, but this partly reflected relatively poor productivity growth from 1977 to 1982. For the most recent decade, productivity growth in wholesale trade in particular was relatively strong.

8. 1.6 and 1.4 percentage points respectively.

9. Owing to the poor quality of the data, Statistics Canada does not publish productivity estimates for: logging and forestry; mining, quarrying and oil wells; utilities; and finance, insurance and real estate (FIRE). Unpublished numbers for FIRE, produced here with the permission of Statistics Canada, are included in the table. 
FIGURE $3 \quad$ Productivity in Service Industries 1961-94

(Annual Index of Output per Person-Hour)

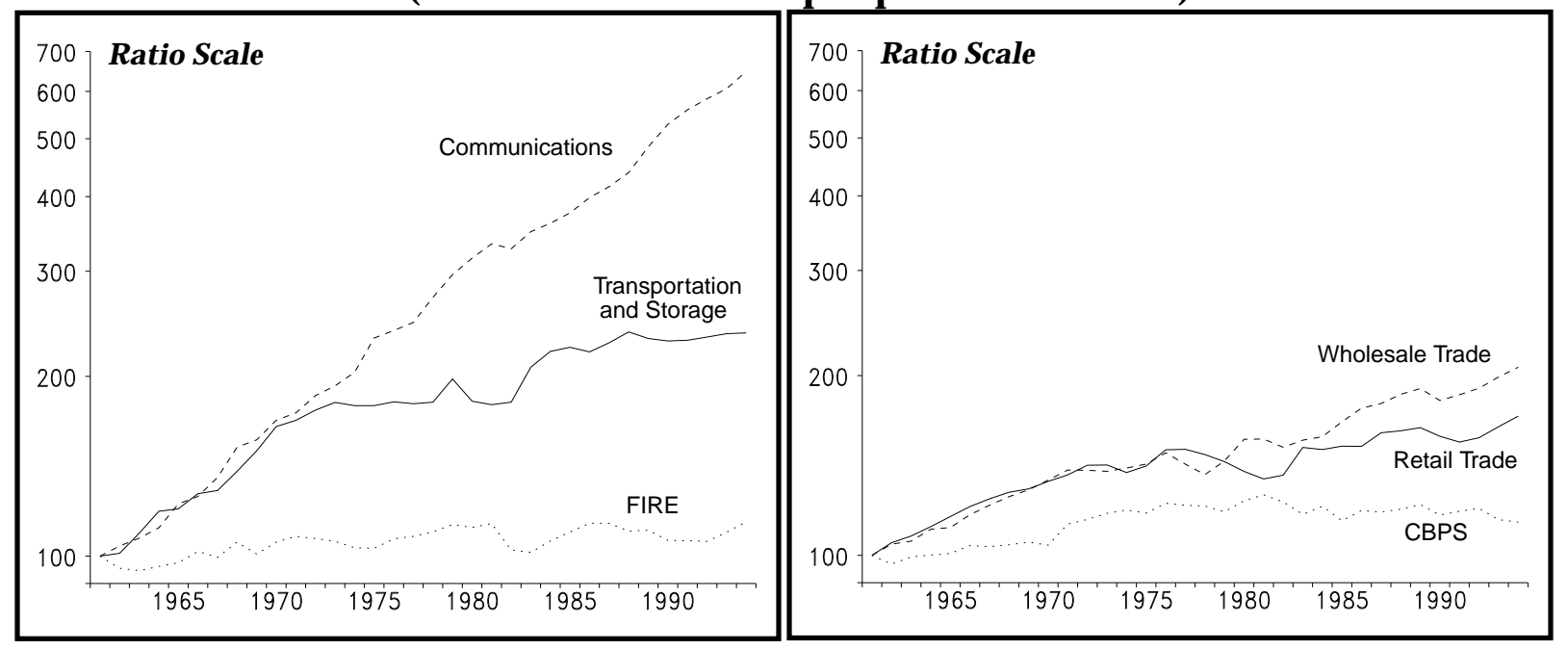

Table 1: Mean Productivity Growth Per Person-Hour

\begin{tabular}{l|c|c|c||c|}
\hline \multicolumn{1}{c|}{ Industry } & $1961-94$ & $1961-71$ & $1971-81$ & $1981-94$ \\
\hline \hline Goods & 3.0 & 5.0 & 2.4 & 1.9 \\
\hline Agriculture & 4.1 & 8.6 & 1.7 & 2.5 \\
\hline Manufacturing & 2.9 & 4.3 & 2.5 & 2.1 \\
\hline Construction & 1.2 & 0.9 & 2.9 & 0.0 \\
\hline Services & 1.6 & 3.0 & 1.3 & 0.9 \\
\hline $\begin{array}{l}\text { Transportation and } \\
\text { storage }\end{array}$ & 2.7 & 5.4 & 0.7 & 2.2 \\
\hline Communications & 5.9 & 5.7 & 6.8 & 5.3 \\
\hline $\begin{array}{l}\text { Community, business } \\
\text { and personal services }\end{array}$ & 0.4 & 1.3 & 1.2 & -0.8 \\
\hline Retail trade & 1.7 & 3.2 & -0.1 & 1.9 \\
\hline $\begin{array}{l}\text { Wholesale trade } \\
\text { Finance, insurance } \\
\text { and real estate }\end{array}$ & 2.3 & 3.4 & 1.3 & 2.2 \\
\hline
\end{tabular}

a. Unpublished data provided by Statistics Canada 
The two service industries with undeniably lagging productivity growth are community, business and personal services (CBPS) and finance, insurance and real estate (FIRE). Both had very low average productivity growth for the period as a whole ( 0.4 and 0.5 per cent respectively). ${ }^{10}$

Within the goods sector, agriculture recorded productivity growth above the sectoral average for the period as a whole, thanks to strong gains early in the period. This occurred at the end of a long period of restructuring that saw a large part of the work force move out of the farm sector. Manufacturing productivity growth was a little below that for goods in total. Construction recorded relatively low productivity growth.

\subsection{Multifactor Productivity}

Calculations of multifactor productivity take into account capital inputs as well as employment and hours. For the value-added measure of multifactor productivity, Statistics Canada publishes data only for the total economy and manufacturing, because of concerns about the quality of the sectoral numbers. The unpublished numbers for annual multifactor productivity for the goods and service sectors are shown here in Figure 4, however, with the permission of Statistics Canada. Table 2 shows the mean growth in multifactor productivity, again using value-added measures for the sectors and gross-output multifactor productivity for the individual industries.

The multifactor productivity data are broadly consistent with the labour productivity numbers, with the goods sector experiencing a higher average growth rate of productivity than the service sector (1.4 versus 0.6 per cent for the period 1962-91). Similarly, the gross output multifactor productivity data show relatively good growth in communications, transportation and both retail and wholesale trade, but declines in business services, and finance and real estate.

There is a much greater correspondence between cyclical changes in multifactor productivity in the goods and service sectors than cyclical changes in labour productivity. The declines in the productivity of goods and services are quite similar during downturns using a multifactor measure, although different factors contribute to the declines. In the goods sector, increases to capital stock peaked in the same years that output fell.

10. It should be stressed, though, that the productivity series for FIRE is considered to be of poorer quality than the other series. 
FIGURE 4 Annual Change in Multifactor Productivity (Annual Index of Value-Added Measure 1960=100)

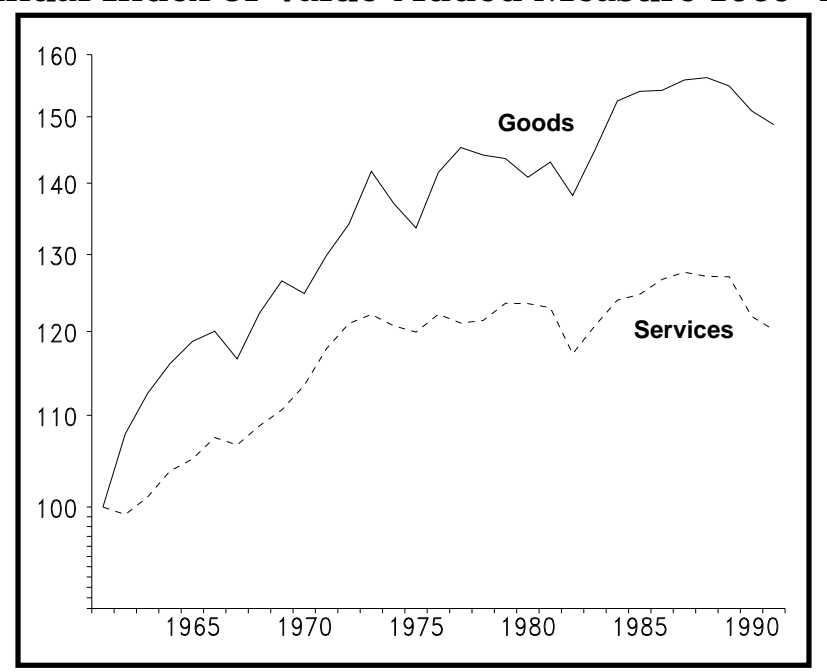

Table 2: Mean Growth in Multifactor Productivity ${ }^{\text {a }}$

\begin{tabular}{l||c|c||c|c|}
\hline \multicolumn{1}{c|}{ Industry } & $1961-92$ & $1961-71$ & $1971-81$ & $1981-92$ \\
\hline \hline Goods $^{\mathrm{b}}$ & 1.4 & 2.7 & 1.0 & 0.4 \\
\hline Manufacturing & 0.6 & 1.1 & 0.7 & 0.1 \\
\hline Construction & 0.3 & 0.5 & 0.9 & -0.3 \\
\hline Uutilities & 1.1 & 2.9 & 1.3 & -0.6 \\
\hline \hline Services ${ }^{\mathrm{b}}$ & 0.6 & 1.7 & 0.4 & -0.2 \\
\hline Communications $^{1}$ & 3.6 & 3.8 & 4.7 & 2.5 \\
\hline Transportation $^{\mathrm{c}}$ & 1.3 & 2.5 & 0.6 & 1.0 \\
\hline Retail trade & 1.1 & 2.3 & 0.3 & 0.7 \\
\hline Wholesale trade & 1.7 & 2.8 & 1.3 & 1.1 \\
\hline Business services & -0.1 & 0.1 & -0.2 & -0.1 \\
\hline $\begin{array}{l}\text { Finance and real } \\
\text { estate }\end{array}$ & -1.6 & -1.4 & -1.4 & -2.0 \\
\hline
\end{tabular}
a. Gross-output measures except sector totals
b. Value-added measure, up to 1991 only
c. Not including storage 


\subsection{An Alternative Measure of Productivity}

For analytical purposes, rough measures of productivity can be calculated using the monthly measure of GDP at factor $\operatorname{cost}^{11}$ as output, and Labour Force Survey (LFS) data for employment and hours by industry. ${ }^{12}$ This may be done, for example, to obtain measures of productivity by province, to develop more detailed industry groupings or to calculate data with a greater frequency than the annual indexes. While the rates of change of these measures should be similar to those of the annual indexes, their calculation is somewhat cruder. It is important to check, therefore, how close these calculations are to the growth rates of the indexes of productivity. Appendix 1 provides full details on how the series used for comparison are created, as well as a detailed comparison of the results by industry. To summarize, at the sectoral level, the profiles of productivity growth per person as calculated using GDP and LFS data are very similar to those of the productivity indexes. At the industry level, however, greater differences emerge. The calculated numbers provide general indications of average growth and the ranking of industries. But disparities between the two measures suggest the data are considerably less reliable at more detailed levels.

\subsection{Summary}

Most of the stylized facts presented here are well known:

- Service-sector labour productivity growth has consistently lagged behind that of the goods sector for over three decades. While the differential has narrowed in recent years, it is the slowing of goods-sector productivity growth that is responsible, rather than an increase in service-sector productivity growth.

- The differential in the labour productivity growth of goods and services is smaller on an hours-worked basis.

- Preliminary data on multifactor productivity show trends that are broadly consistent with those found in the labour-productivity data.

These aggregate numbers, however, conceal broad disparities in productivity performance among service industries. In fact, low productivity growth is not characteristic of all service industries. Some service industries, notably communications and transportation, have shown strong productivity growth. If low-productivity industries are the concern, therefore, the commercial service sector is too broad a definition for analysis. Rather, the focus should be on FIRE, CBPS and, to a lesser extent, trade.

11. For a detailed description of the data see Statistics Canada, Gross Domestic Product by Industry, Catalogue 15-001, June 1994.

12. Disaggregated employment by industry from the LFS was obtained from Statistics Canada. The hours measure used was average actual hours worked, with no adjustments for reference week problems or seasonal adjustment. 


\section{A Problem of Mismeasurement?}

\subsection{The Problem}

Many researchers have suggested that an important source of the differential in productivity growth between goods and services is measurement error. ${ }^{13}$ They argue that problems in defining service-sector outputs and identifying price versus quality changes, as well as the paucity of data on services, have resulted in underestimation of service-sector output growth.

At a general intuitive level, it is not hard to make a convincing argument in favour of measurement errors leading to underestimation. General problems that are frequently discussed include:

- the greater difficulty involved in defining output and assessing quality change for the service sector compared with the goods sector. While there are major problems with measuring productivity for both the goods and service sectors, defining a unit of service output is often thought to be harder because of problems such as its greater intangibility and the the fact that quality depends on the inputs provided by the user of the service. These conceptual problems translate into practical difficulties, such as less standardization of data reporting.

- the poorer quality of data on services than on goods. This is due in part to poorer survey coverage. For example, Statistics Canada has published the fraction of current dollar GDP that is "estimated" for each service industry. ${ }^{14}$ The largest estimated components belong to wholesale and retail trade (26 per cent and 20 per cent respectively). Around 11 per cent of CBPS is estimated, and 10 per cent of transportation and storage. FIRE and communications have the lowest proportion of estimations, at 4 per cent and 1 per cent respectively.

- the high proportion of certain service outputs that are intermediate inputs elsewhere. This further complicates measurement, since data on intermediate inputs are generally harder to obtain than data on final outputs. In business services, for example, over 80 per cent of output ${ }^{15}$ is an intermediate input elsewhere, and for transportation over three-quarters of output is used as intermediate inputs. While these two industries have the highest ratios, many other service industries have over half of their output used as intermediate inputs.

- inappropriate deflators that cannot account for many quality improvements. Price increases resulting from quality increases, for example, may be treated as pure price increases, thus creating a downward bias in real output.

13. For example, see Griliches (1992).

14. Statistics Canada, Service Industries in the Canadian Input-Output Accounts, Cat. 15-601E, Vol. 2. The estimated portion includes upward adjustments for undercoverage of surveys, estimation of details from partial information and interpolations between occasional surveys.

15. Taken from Economic Council of Canada, 1991, Employment in the Service Economy, p. 36. 
- growth in the underground economy, which may not be taken fully into account in the data. Examples include the construction trades and child care which may be paid for "under the table."

It is much harder, however, to move beyond general examples to a rigorous analysis of the extent and direction of measurement errors. The impact of inappropriate deflators or incorrect output measures, for example, depends crucially on the specific models and data being used at the sub-industry level. A proper analysis, therefore, requires consideration of the methodology and data used for each of the sub-industries. Not surprisingly, few people have the resources to embark on this kind of study. As a result, most studies that try to empirically assess or quantify measurement problems concentrate on specific industries. While such studies make very important contributions to the debate, the results can not necessarily be generalized to other industries.

For these reasons, the literature on the importance of measurement errors at the sectoral level is unsatisfactory. Authors are often undecided or reach conclusions that appear to have more to do with their initial beliefs than any rigorous analysis. The lack of credible conclusions is, however, a reflection of the complexity of the issues and, perhaps, of the relative inattention paid to measurement issues by data users.

This paper, unfortunately, follows in this tradition, in that it reaches no overall conclusion on the importance of measurement errors. Rather, since low productivity growth is a major concern, it was decided to focus attention on the three service industries that had experienced the lowest measured productivity growth. This section, therefore, reviews possible areas of measurement error in FIRE, CBPS and trade. Appendix 2 gives additional details on how these data are constructed. A full assessment of the extent of measurement errors in these industries would, of course, require derivation of alternative output and labour input data, free from any of the possible biases occurring in the published data. Such an exercise is, however, beyond the scope of this paper. Instead, measured productivity growth is compared with anecdotal evidence, on the grounds that where the two are consistent there is less likely to be a major problem than in cases where the two are very different, particularly when the differences are in line with potential biases in the data. It is recognized that the anecdotal evidence may itself not always be reliable.

\subsection{Finance, Insurance and Real Estate ${ }^{16}$}

The main components of FIRE are: banks, credit unions and other deposit-accepting institutions (around 25 per cent of the total); trust, other finance and real estate companies (around 67 per cent of the total); and insurance industries (around 9 per cent of the total).

16. FIRE is generally defined to include government royalties on natural resources and imputed rent from owner-occupied dwellings, but these are excluded from the output measurement for the purposes of calculating productivity. 


\subsubsection{Data}

FIRE provides an example of an industry where the anecdotal evidence is at odds with the productivity data. Productivity growth in FIRE (as measured by output per personhour) was very slow over the period 1962-94, averaging only 0.5 per cent a year (as shown in Section 2). For the period 1982-94, productivity was flat. These data contrast sharply with much of the anecdotal evidence concerning the sweeping changes brought about by the introduction of information technology. These changes include:

- improvements in the internal management of banks through computerization of activities such as records-keeping and accounting

- the development of inter-bank linkages, such as the establishment of networks by credit card agencies and the ability to transfer funds electronically

- computerization of financial markets and the use of complex software to monitor the supply of and demand for various financial products, for example stock exchange activities ${ }^{17}$

Of course, there are plausible explanations for the seemingly different pictures presented by the anecdotal evidence and the data. The anecdotal evidence, for example, may illustrate improvements in only a small share of the industry. In addition, productivity improvements stemming from new technology may be overshadowed by other changes, such as an expansion in the number of branches, that might have tended to lower measured productivity growth. According to figures obtained from the Canadian Bankers' Association, the number of bank branches in Canada increased from around 7,000 in 1985 to about 8,000 in 1996.

FIRE is also one of the more difficult industries to measure. Both conceptual and data problems are considerable. It should be remembered that Statistics Canada does not publish a series on productivity for FIRE because of concerns about the quality of the data. What is, for example, the output of a bank: the number of transactions people perform at the bank? the convenience? safekeeping? the amount people are willing to pay in order to have their money held by the bank? Moreover, there are specific problems with the measurement of FIRE that likely produce not just uncertainty, but also underestimation. These are identified below.

17. These three stages of technology adoption were characterized by Petit (1991). 
How is the Output of a Bank Measured?

$$
\begin{aligned}
& \text { imputed service charges + volume of services, where explicit } \\
& + \text { other revenue (e.g., rent) service charges made }
\end{aligned}
$$

Imputed services: total interest payments on loans and on deposits are deflated by the total CPI, and the difference between loan and deposit real interest payments is calculated. This is then adjusted for changes in the service margin, i.e., the difference between the interest rate spread for loans and deposits. (Changes in the margin are treated as price changes.)

Explicit services (service charges levied directly): total receipts from such services are deflated. The deflator uses published rates on certain standardized services, e.g., processing cheques. But Statistics Canada does not have good information on many of the charges. Charges such as credit card fees and ABM fees, for example, are not identified.

\subsubsection{Areas of Possible Downward Bias and Uncertainty}

The area of FIRE that often receives most attention in discussions of measurement problems is banking. As described in the box above, the output of banks consists of two main categories: the deflated value of receipts for services, where explicit service charges are made; and imputed service charges based on the volume of loans and deposits. There are potential measurement problems in both calculations.

The measure of nominal output for imputed services is the value-added of bank deposit and loan activities. Statistics Canada treats changes in the service margin between loans and deposits as price changes, so that factors that affect this interest rate margin do not affect real output. For example, a decrease in the interest rate spread due to increased competitive pressures would show up, appropriately, as a price decline, not a change in real output. More problematic is the deflation of the value of loans and deposits by the CPI. The choice of deflator is by no means straightforward. Should the measure of real output, for example, reflect the volume of loans, implying that real output is best expressed as the number of loan transactions? Alternatively, should the deflator merely reflect the general costs of banking so that real output is not purely transactions-based, but counts a large loan as higher output than a small loan? Evidently, the choice of deflator depends a lot on the initial definition of banking output. The choice of the CPI suggests that Statistics Canada is trying to use a measure of general costs. The index is, too general to provide a good indicator of banking costs, however. Moreover, to the extent that the CPI is upwardly biased, it may lead to overdeflation and thus to an underestimation of real output growth.

In the case of explicit service charges, the most important problem is likely the sparsity of data. The deflator for explicit service charges does not include many important charges, such as credit card fees. Thus the level of uncertainty surrounding this deflator is very high. 
Partly because of this uncertainty, there are a number of complex changes that have affected explicit service charges and interest rate spreads that may not have been accounted for in the data. Explicit service charges and interest rates, such as the deposit rate, are to a large extent pricing substitutes: a bank may, for example, lower an effective deposit rate by establishing a no-interest minimum balance rather than explicitly charging for transactions. It is not obvious that the deflators used are comprehensive enough to pick up the full impacts of charge/interest rate adjustments that are merely changes in how costs are recovered. Neither is it clear, however, whether this would lead to a downward or upward bias.

Other measurement problems leading to possible downward bias include:

- credit unions, investment funds and the Bank of Canada, where zero productivity growth is assumed. Output is equivalent to operating costs.

- consumer loans (where the deflator is heavily based on employment compensation), real estate commissions, and stock broker fees, which have been identified by Statistics Canada as areas where overdeflation is likely occurring. They are working to produce alternative deflators.

- activities that have experienced recent rapid growth, in particular mutual funds, which did not become important until the 1990s. The data sources here are poor and may well understate the productivity increases that have occurred.

A more general problem comes from the fact that new technology is an important input for FIRE. Quality improvements stemming from the application of new computing and telecommunications technologies are frequently cited as being extremely hard to measure. ${ }^{18}$ It is interesting to note in this context that the communications industry has experienced extremely high productivity growth. Since this industry provides important inputs to FIRE, there may be areas where productivity growth is appearing in the input industry, rather than FIRE. It is, however, also important to remember that, as well as unmeasured gains in areas such as convenience, there have likely been unmeasured losses associated with new technology. For example, some work formerly done by tellers is now undertaken by customers using ABMs. As a result customers assume a greater share of risk than they did previously.

In Canada, the use of a hedonic index for deflating computer prices may upwardly bias the output of computer manufacturing at the expense of compuer-using industries where hedonic deflating is not used. Currently, computer manufacturing is one of the few places where a hedonic price index is used. This results in a much faster decline in computer prices than would occur with an index using a more traditional method of quality adjustment. Since in most cases real GDP is calculated using double deflation, in the case of computer inputs, improvements in the computers will be fully reflected in the computer manufacturing industry data, and not appear as improvements in the final product. For many other inputs, however, quality improvements may not be fully reflected in the output of the industry providing the input, but rather will appear as

18. See, for example, Baily and Gordon (1988). 
increased output of the user industry. Productivity growth may, therefore, appear relatively lower in those industries using computers as inputs compared with industries using other kinds of inputs. It should be stressed that these problems are not due to the fact that hedonic methods are inappropriate, but to the fact that only one product is deflated in such a way.

\section{Double Deflation}

In Canada, for all industries except construction and trade, real GDP is calculated using double deflation.

Double deflation involves subtracting the real value of intermediate inputs (nominal inputs deflated by input prices) from real gross output (nominal output deflated by output prices).

This yields real value-added for each industry.

The overall conclusion is that underestimation may be severe in at least the area of banking and financial institutions. It is hard, however, to obtain alternative measures of output in these areas to compare with the official data. Studies that have attempted to calculate such measures (mostly for the United States rather than Canada) tend to find poor productivity growth. The conclusion of such studies is that even their "improved" measures have failed to pick up changes such as cash management improvements, the benefits of ABMs and improved productivity from deregulation and increased competition. $^{19}$

\subsection{Community, Business and Personal Services}

Measured productivity growth in CBPS was very low-only 0.4 per cent per year-for the period 1962-94. The industry includes, however, a diverse mix of activities. A little over a third of CBPS output is accounted for by business services, which include the high-tech (and apparently high productivity growth) software industry. At the other extreme are personal and household services (7 per cent of the total), which include traditional services that typically are thought of as least amenable to productivity growth, such as hairstyling and dry cleaning. Other main categories within CBPS are health services (18 per cent), accommodation and food services (18 per cent) and amusement and recreation services (7 per cent).

The areas where underestimation is most likely to occur are concentrated in business services:

- Measurement of the software industry output has been greatly improved by the adoption of a deflator based directly on software prices, rather than on

19. For example, see Bauer, Berger and Humphrey (1993) for a review of a number of studies looking at total factor productivity in the U.S. banking industry. 
wages. The high technology sector is nevertheless an area of rapid change and sparse data, so that recent quality improvements may well be undermeasured. Such undermeasurement would, in turn, result in overmeasurement of productivity in industries for which software is an important input.

- The productivity growth of professional services may also be underestimated. For example, in the case of architects and accountants, the deflators are based on average weekly earnings, which will likely overdeflate output since wages themselves should, over time, correspond to the marginal product of labour.

\section{Question: For intermediate inputs, where should productivity gains appear?}

For example: a new software package allows firms to reduce the number of employees for a certain task.

Should the increase in productivity appear:

* in the service sector firm that developed the product (which replaced a product of lower quality)?

* the goods-sector firm that implements the package and thereby reduces labour inputs?

* some combination of the above?

Currently: assuming the new package takes the same labour inputs to produce as the old, and costs the same, the gains will appear in the goods sector. This is not the case, however, for computer hardware. Since output is deflated by a hedonic index that takes account of quality increases, the productivity increase will appear at least partly under computer manufacturing, not in the industry actually using the computer hardware.

In addition, some deflators for private sector education and health-service activities are based on costs in the public sector. Data on public service activities are also relatively scarce, leading to considerable uncertainty in this area.

Taking into account both the identified problems in measurement and anecdotal evidence on productivity, it is likely that some underestimation of business services is occurring. Moreover, there is considerable uncertainty surrounding many of the estimates for personal services, but no obvious indication of a systematic downward bias. 


\subsection{Retail and Wholesale Trade $\mathrm{e}^{20}$}

The retail and wholesale trade industry can broadly be defined as those firms whose main activity is buying and reselling merchandise. They provide a number of specific services, including "matching" potential customers to suppliers, and providing information about products, packages and processing. The quality of their output depends on such diverse factors as their product selection, the dependability of their products, presentation, waiting times for assistance and the proximity of stores to parking and public transportation.

Growth in labour productivity, as measured by the index of output per person-hour, has been much stronger for retail and wholesale trade than for FIRE or CBPS. For the period 1962-94, it averaged 1.7 per cent for retail trade, and 2.3 per cent for wholesale trade. In the most recent decade, productivity growth in wholesale trade has been above that of the aggregate goods sector, and productivity growth in retail trade has been equal to that of the goods sector. In addition, the gross output multifactor productivity data show relatively strong productivity growth in trade. These data are broadly in line with the anecdotal evidence, which suggests that a number of productivity improvements have occurred in recent years, owing in part to investment in new technology. Recent innovations include: streamlining many back-room operations through computerization, and more careful scheduling of employees around periods of high and low activity.

Nevertheless, a close look at Statistics Canada's methodology suggests that the data may well be downwardly biased. To understand this, it is necessary to explain the way in which GDP is calculated for this industry. Statistics Canada's measurement of real GDP in the trade industry is done on a different basis from that of most other industries. Output is based on value-added or the real trade margin, i.e., the difference between the value of sales and the cost of the products purchased for resale. Consider, for example, the calculation of GDP for wholesale trade:

- For each commodity, the real "wholesale trade margin" is calculated for the base year and the current year. This margin equals the gross wholesale margin (the difference between the price at which the good is sold and the price paid for it originally), deflated by the producer price of the good.

- The margins for the current year and the base year are averaged.

- The margin is multiplied by the constant-dollar producer value of the good to yield a GDP measure.

- These measures are then aggregated across commodities.

20. The division between wholesale and retail is, in most cases, based on whether the larger share of the gross margin is derived from sales to retailers, institutions and/or professional users (in which case they are classified as wholesalers) or from sales to households (retailers). Dealers mainly concerned with office furniture, lumber and building materials, farm machinery, commercial retailers, fuel oil and all types of industrial and commercial machinery are always classified as wholesalers, irrespective of whom they sell to. 
Thus only quality improvements that result in increased trade margins will be reflected in the measurement of output. Similarly, other changes to the margin, which are not related to the quality of the service provided, will affect the measurement of output. For example:

- Assume that retailers increase the number of employees in order to decrease customer waiting time while the volume of sales remains unchanged. The retailers increase their margin in order to recoup the increased labour costs. The actual result could be considered an increase in the quality of output and labour productivity will likely be unchanged or increased. The data would also show an increase in real output, since margins have increased, though the increase in real output would not be as great as the increase in nominal margins, so there would also be a price increase. The data would, therefore, fairly accurately reflect the increase in output quality.

- Assume that there is increased competition, due perhaps to the entrance of foreign-owned competitors expanding into Canadian markets. Retailers cannot pass on input cost increases and trade margins fall across the industry. The data would show a fall in output and productivity.

In recent years the level of competition in the Canadian retail industry has substantially increased with the entry of a number of large U.S. chains, encouraged by such factors as the internationalization of retail trade, the decline in cross-border shopping and changes in rules concerning foreign ownership. This has put pressure on trade margins, so that many improvements in output quality have not been reflected in trade margins.

Industry commentators state, for example, that many margins fell as the value of the Canadian dollar dropped, since merchants were not able to pass through the increased cost of imports. Since the calculation of real output involves multiplying the average of the current year margin and the base year margin by the constant-dollar producer value, assuming no change in the latter, the fall in trade margins will appear partly as a drop in price but also partly as a drop in output. It should be noted, however, that there may also be a bias in the opposite direction, if changes are being made that result in lower quality service to the customer.

In addition, it should be noted that data coverage for trade is less complete than in most industries. In the past, data for calculating trade output came from a variety of censuses of varying degrees of frequency and coverage, as well as administrative (tax)

information. There was considerable interpolation of the elements of GDP both between census years and at the level of industry detail. Since 1982, both the wholesale and retail trade industries have been covered by annual surveys that provide data on volumes of trade, sales and receipts, purchases, inventories, wages and salaries by establishment. Where possible, benchmarks from occasional surveys of specific store types are also included. Nevertheless, a considerable share of GDP is "estimated": 26 per cent for wholesale trade and 20 per cent for retail trade. 
It is interesting to compare the labour productivity numbers (the index of output per person/hour) with an alternative measure: real sales per employee. ${ }^{21}$ These are shown for wholesale and retail trade separately in Figure 5. Both measures show similar trends, particularly in the case of retail trade. For wholesale trade, the measure of sales per employee shows greater variation than the measure of output per person-hour.

\section{FIGURE 5 Productivity Growth vs. Sales per Employee (Percent Change in Index of Output per Person-Hour and Real Sales per Person)}

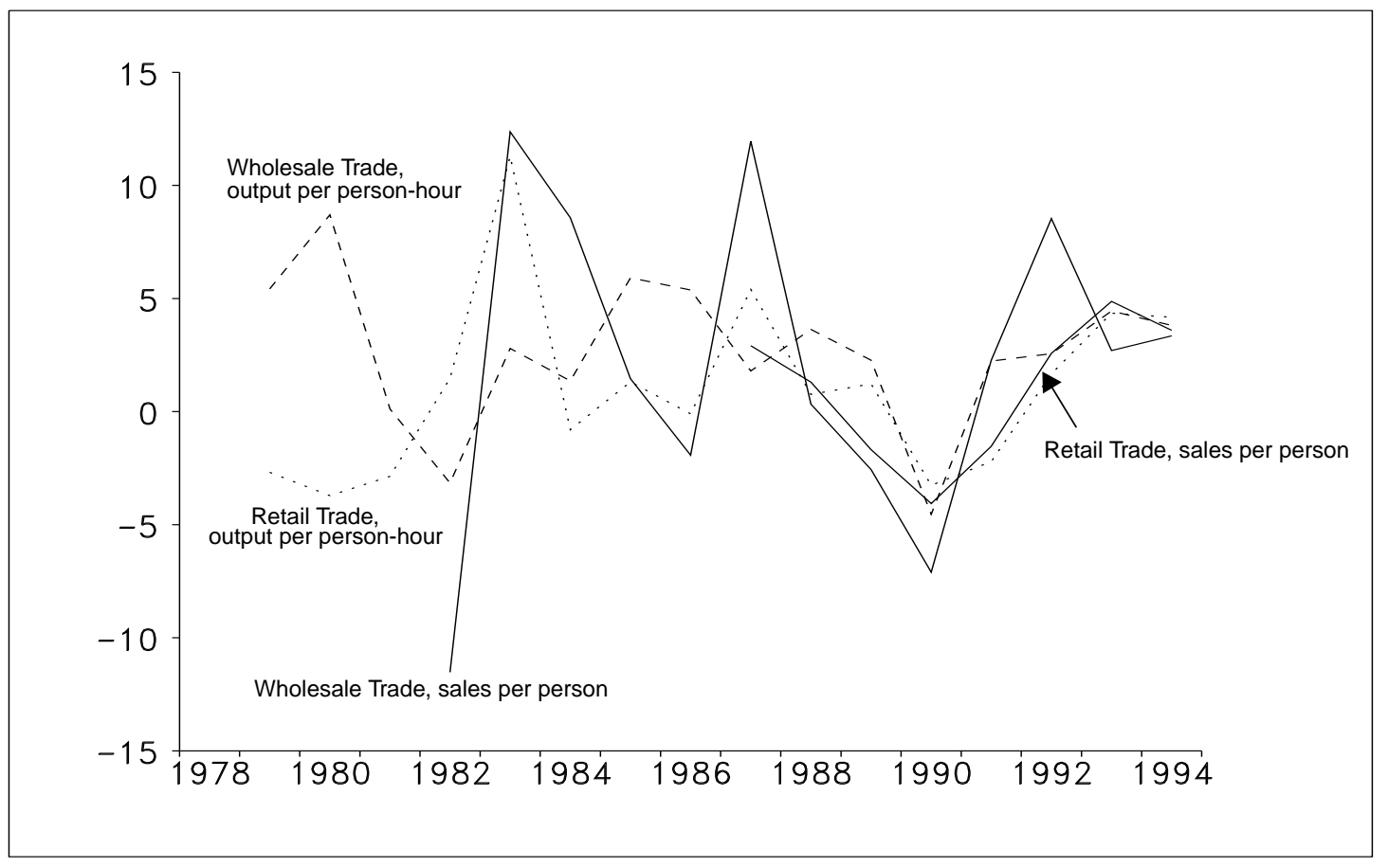

In summary, recent productivity growth and anecdotal evidence are not inconsistent. Considering the methodology, however, and the impact on margins of increased competition in the sector, it is probable that some recent quality improvements have not been reflected in the output measure. Thus it is quite probable that productivity has been underestimated in the trade sector, but it is not clear that this underestimation is significant.

\subsection{Conclusion and Implications}

In the more detailed analysis of the three service industries with the slowest measured productivity growth, it was suggested that underestimation is likely significant in FIRE and business services. Underestimation of trade productivity is also likely in recent years, since trade margins have narrowed as a result of increased competition within the industry. In all cases, it is the adjustments for price changes that appear to cause the most severe problems, rather than the measurement of nominal output.

21. For retail trade, this figure is calculated as constant-dollar retail sales divided by employment in retail trade; for wholesale trade, as nominal wholesale trade deflated by the producer price index. 
The fact that measurement errors have been found to be appreciable in specific industries raises questions about whether growth in total GDP and productivity are being underestimated. The consensus of the literature is generally that it is not, because the measurement of final goods and services is thought to be adequate. To the extent that this is true, mismeasurement merely causes errors in the distribution of output between industries. It is not clear, however, that quality changes even in final goods and services are always well captured or if this quality problem is worse for services than goods. A full analysis of the implications for total productivity would require a detailed examination of measurement problems in both the goods and service sectors. 


\section{Mismanagement of New Technology?}

Stephen Roach has suggested that lagging productivity in services in the 1980s was in part a result of overinvestment in information technology. ${ }^{22}$ He claims that not only did service firms invest too much in new computer technology, but that the long learning period associated with the new technology also reduced the visible benefits from these investments. Often, for example, new systems operated side-by-side with the old systems, so that tasks were done twice.

Investment in computers has been relatively high in the service sector. This can be seen in Table 7, which shows the ratio of investment in computers to total gross real business investment in machinery and equipment by industry. ${ }^{23}$ At best, however, overinvestment in computer technology offers an explanation for the slower productivity growth in services in the 1980s. Yet slower service-sector productivity has been a much longer-term phenomenon, as shown in Section 2. Moreover, the criticism of overinvestment assumes that prudent investments would have produced immediate productivity gains. Yet there is a considerable literature suggesting that there may be long lags between the introduction of new technology and productivity growth. In the United States, consideration of these issues was sparked in particular by concerns over the slowdown in productivity growth in the late 1970s and early 1980s.

There are a number of factors that can delay the visible benefits of new technology. For instance:

- The adoption of new technology usually involves learning periods that show up as decreased productivity, because improvements in human capital are not captured in the data. Moreover, many of the skills will likely be acquired through "learning by doing" and such a learning process may well include making errors that register as "mismanagement."

- Initially, technology is used largely to improve the way in which traditional tasks are performed. It takes greater familiarity with the potential of new technology before more fundamental changes in organization and the production process can be implemented to better exploit the technology.

- Significant productivity gains will not be seen until the effective use of new technologies is widespread. Measured productivity growth reflects the average practice rather than the best practice.

- Diffusion of technology may be slow because of the substantial fixed costs of changeover and because of uncertainty about the benefits and vintage effects-it takes time to adapt the structure of capital and it does not make economic sense to scrap old equipment immediately.

22. See, for example, Roach (1991).

23. It should be noted that the data for manufacturing is downwardly biased, since expenditures on computer-assisted processing equipment are not included in investment in manufacturing equipment. 
Table 7: Ratio of Real Investment in Computers to Total Gross Investment in Machinery and Equipment by Industry (Per Cent) ${ }^{a}$

\begin{tabular}{c|c|c|c|c}
\hline Year & $\begin{array}{c}\text { Agriculture, } \\
\text { Forestry and } \\
\text { Mining }\end{array}$ & Manufacturing & $\begin{array}{c}\text { Trade, Finance } \\
\text { and Business } \\
\text { Services }\end{array}$ & Utilities $^{\mathrm{b}}$ \\
\hline 1985 & 1.4 & 3.7 & 13.4 & 6.3 \\
\hline 1986 & 1.8 & 4.0 & 16.1 & 8.5 \\
\hline 1987 & 2.5 & 5.0 & 22.5 & 7.5 \\
\hline 1988 & 2.4 & 5.3 & 22.8 & 5.1 \\
\hline 1989 & 1.1 & 6.0 & 35.8 & 8.6 \\
\hline 1990 & 1.3 & 7.1 & 39.1 & 8.5 \\
\hline 1991 & 1.9 & 8.2 & 43.5 & 12.6 \\
\hline
\end{tabular}

a. Data from Statistics Canada, Capital Expenditures on Machinery and Equipment by Type of Asset 1985-1991, Catalogue 61-223. Data after 1991 are based on updated SIC codes; thus classification between industries is not strictly comparable with previous data.

b. Includes transportation, communications and other utilities

David (1991) points out an interesting parallel between the current spread of new technology and the impact of electrification and the associated adoption of the dynamo. He points out that measured productivity in the United States was declining during the period of the initial spread of electrification, probably in part because quality improvements associated with the use of electricity for lighting and urban transportation were not captured in the data. It was not until 40 years later that big productivity increases became evident. It took that long for generation plants to become large enough to achieve significant economies of scale that reduced costs enough to promote widespread electrification of manufacturing. It was only then that organizational changes were made and production processes were rationalized to fully benefit from new methods of production.

A somewhat different view, perhaps more in line with Roach's comments, is the idea that humans are the bottleneck limiting productivity improvements. Ayres (1991) suggests that while new technologies are capable of providing huge amounts of information, people are severely limited in their ability to process it all. Too much information of the wrong kind is being produced, leading to problems of overloading and interference.

In addition, there are considerable problems in measuring quality improvements and new products associated with technological change, in part because of the rapidity of change and poor sampling. This is exacerbated by the fact that some of the greatest gains from technological advances have come in hard-to-measure service industries like finance and banking. 
In conclusion, it is evident that the service sector has invested heavily in new computer technology and that there have not been visible productivity gains from this investment. It is not clear that the failure to realize productivity growth is the result of poor investment decisions or of mismanagement of the new technology. Even excluding measurement problems, there are good reasons to suggest that productivity gains may not become evident until the technology is widespread, until technology-specific human capital is more common, and until there have been significant organizational changes to take advantage of the full potential of new technology. Unfortunately there is no clear empirical evidence to resolve the issue. At best, however, the hypothesis of overinvestment in computing provides only a very short-term explanation of the disparity in productivity growth between goods and services. Moreover, it only explains the disparity to the extent that the service sector has invested more heavily than the goods sector in new technology. 


\section{Lack of Competition?}

Another explanation for lower productivity growth in services is that the service sector is subject to less competition than the goods sector. Roach (1991), for example, comments that the failure of the service sector to implement the same kind of productivityincreasing restructuring as the manufacturing sector in the 1980s was a direct consequence of its lack of exposure to competition. There are two main reasons why the service sector may be subject to less competition than the goods sector: a higher level of regulation, including foreign investment controls; and less exposure to foreign trade. The latter stems not only from trade restrictions, but also from the very nature of services, which often cannot be provided at a distance.

Many studies have tried to assess the impact of regulation and competition on efficiency and productivity. Most of these have concentrated on the impacts on the level of productivity rather than growth rates. Baily (1993), for example, compares regulation and efficiency across five countries (France, Germany, Japan, the United Kingdom and the United States) in four service industries (airlines, retail banking, telecommunications and general merchandise retailing). He gives a detailed description of regulations governing the four industries in each of the countries, and then develops his own measures of productivity, which are generally comparable across countries. He finds that, in general, the United States has a relatively high level of productivity compared with the other countries, consistent with its generally lower level of regulation. A similar study was done by Baily and Gersbach (1995) for nine manufacturing industries across three countries: Japan, Germany and the United States They concluded that a major contributor to differences in productivity levels is the way in which functions and tasks are organized. Moreover, they felt that the nature of the competition facing companies strongly influenced productivity levels. In particular, firms only adopt major changes if they are in direct competition with best-practice firms.

In the past it is likely that services were less exposed to competition than goods. Government regulations have been important in industries such as communications, transportation and finance. While it is not hard to believe that this has affected the level of productivity in services, it is less obvious that such regulations would have had an ongoing dampening effect on productivity growth in these industries. In recent years, however, productivity growth has been boosted by deregulation in industries such as transportation and communications.

Similarly, international trade has historically been less prevalent in services than in goods, but it is increasing. For example, new technology is facilitating international trade in services, with information technology allowing more services to be provided at a distance. Little work has been done to assess the impact of such changes on productivity growth.

In conclusion, it is likely that regulations and less exposure to international trade have had an impact on the level of service-sector productivity, though competition is now increasing. It is unclear, however, to what degree rates of growth have been depressed for long periods by regulations, or the extent to which services have been more sheltered from competition than goods. An exhaustive analysis of whether the service sector is subject to less competition than the goods sector and how changes in the degree of 
competition have affected productivity growth would require a detailed assessment of: industry-specific regulations (including health and safety regulations, environment regulations and professional licensing); general regulations such as taxes and benefits and unemployment insurance; restrictions on labour flexibility due to unionization and the nature of labour contracts in an industry; trade restrictions; and the nature of services and the degree to which they are tradeable. 


\section{An Innate Feature of the Service Sector?}

In the 1960s, the development of unbalanced growth models by Baumol (1967) and Fuchs (1968) helped to popularize the notion that because of their labour-intensive nature, service-sector activities cannot be made more efficient through capital accumulation, innovation or economies of scale. They believed that low productivity growth is an innate feature of the service sector. Such ideas remain pervasive today. But while they are valid for some service industries, they should not be applied to the whole service sector.

The main evidence put forward by those supporting the idea of low productivity growth being an inevitable feature of the labour-intensive nature of service industries is anecdotal: a barbershop where there is little that can be done to reduce the time it takes one barber to cut one person's hair; or Baumol's famous example of a half-hour horn quintet which:

calls for the expenditure of 21/2 man hours in its performance, and any attempt to increase productivity here is likely to be viewed with concern by critics and audience alike. ${ }^{24}$

Many efforts to counter these examples are equally anecdotal: for example, the observation that advances in sound production, recording and broadcasting allow one performance of a quintet to be heard by millions of people simultaneously, and re-heard over and over again. It is, of course, questionable how close a substitute a recording is for a live performance.

To try and gauge the importance of this idea in a slightly more methodical manner than swapping anecdote for anecdote, two groups of industries are defined below: industries to which the hypothesis of innate low productivity growth clearly does not apply in light of their past productivity growth; and industries whose low productivity growth may be explained by other factors.

A simple data review leads to a rejection of the notion of innate low productivity growth for half of the service sector.

- The notion of service industries being incapable of productivity growth cannot be applied to the communications industry (10.5 per cent of GDP for the services ${ }^{25}$ ), since it experienced the highest productivity growth of any industry.

- Nor can it be applied to transportation and storage (10.9 per cent of servicesector GDP), since its productivity also grew at a rate close to the average for the goods sector.

- It is also not valid for wholesale and retail trade (30.3 per cent of service-sector GDP). While productivity growth for trade was below the average of the goods sector for the study period as a whole, this largely reflected very slow growth in one decade. In the last decade in particular, productivity has grown

24. Baumol $(1967,416)$.

25. The 1995 annual average excludes owner-occupied dwellings and royalty payments, since these are excluded from productivity measures. 
relatively strongly in trade, which accords with anecdotal evidence. Moreover, it is quite probable that the published figures underestimate true productivity growth in wholesale and retail trade (as argued in Section 3.4 above).

This leaves two industries, FIRE and CBPS, for which the data show undeniably lagging productivity growth. In the case of FIRE, however, it was concluded that underestimation is likely an important factor for banking, credit unions and other deposit-taking institutions (4.5 per cent of service GDP). Similarly, for CBPS a downward bias is probable in business services (11.5 per cent of GDP). This leaves at the most, 33 per cent of the service-sector GDP that might innately have low productivity growth.

It is, however, very dangerous to assume that trends that have occurred in the past must continue into the future. To assume that industries that have shown large increases in productivity growth over recent history will continue to do so in perpetuity is just as unrealistic as to assume that industries that have shown low productivity growth in recent years must always do so. As Griliches (1994) points out, innovations are by their very nature things that no one has thought of before and that therefore cannot be predicted. We cannot tell what changes may be wrought by future developments. 


\section{Conclusion: the Macroeconomic Consequences}

Why has productivity growth in services lagged behind that in the goods sector? A range of factors often invoked to explain lower service-sector productivity growth were reviewed:

- Measurement problems appear to be greater in services than in goods. Defining and measuring quality change is perhaps the single most severe problem contributing to underestimation of real output growth in services.

- A more detailed analysis of the three service industries that experienced the slowest measured productivity growth concluded that underestimation is likely important in FIRE and business services. For trade, the data show relatively strong recent productivity growth, broadly consistent with anecdotal evidence. But the methodology used to calculate GDP in trade has likely produced a downward bias in recent estimates, since trade margins have narrowed in response to increased competition within the industry.

- Explanations based on the service sector's relatively greater investment in new technology are probably not important, and at best account for lagging growth only in the last decade.

- It seems likely that barriers to competition, both government-mandated and those stemming from the nature of service activities, have had an impact on service-sector productivity. The exact importance of these effects, however, and how they compare with barriers to competition in the goods sector are not known.

- The hypothesis that service industries are incapable of high productivity growth assumes that the trends that have occurred in the past must continue into the future, a very questionable assumption. Even if it were appropriate, it would apply to no more than a third of the service sector (parts of FIRE and CBPS).

It was also found that it is incorrect to characterize the entire service sector as experiencing lagging productivity growth. Rates of growth vary greatly across service industries. Moreover, much of the growth in service-sector output is occurring in those industries that exhibit relatively good productivity growth. This can be seen in Figure 6, which shows shares of total output for the service industries. ${ }^{26}$ In terms of output, the share of service-sector output increased by 6.7 percentage points between 1976 and 1995 . More than a third of the increase, 2.7 percentage points, was in communications, an industry showing high productivity growth. Another 1 percentage point was in trade. Just under half of the increase was in an industry with poor productivity growth-CBPS. Yet, even within CBPS, most of the increase was accounted for by the increased share of business services, one of the industries highlighted as a likely area of underestimation.

26. Real GDP at factor cost, measured in 1986 prices. Royalty payments and imputed rent from owner-occupied dwellings have been excluded. To the extent that prices may have risen more slowly than average for some services (the communications industry, for example), the share of that industry's output would be smaller if valued at 1995 prices. Rates of increase for the communications industry, however, would be unchanged, since they are based on volume indicators. 


\section{FIGURE 6 Real GDP in Services as Share of Total Real GDP (1976-95)}

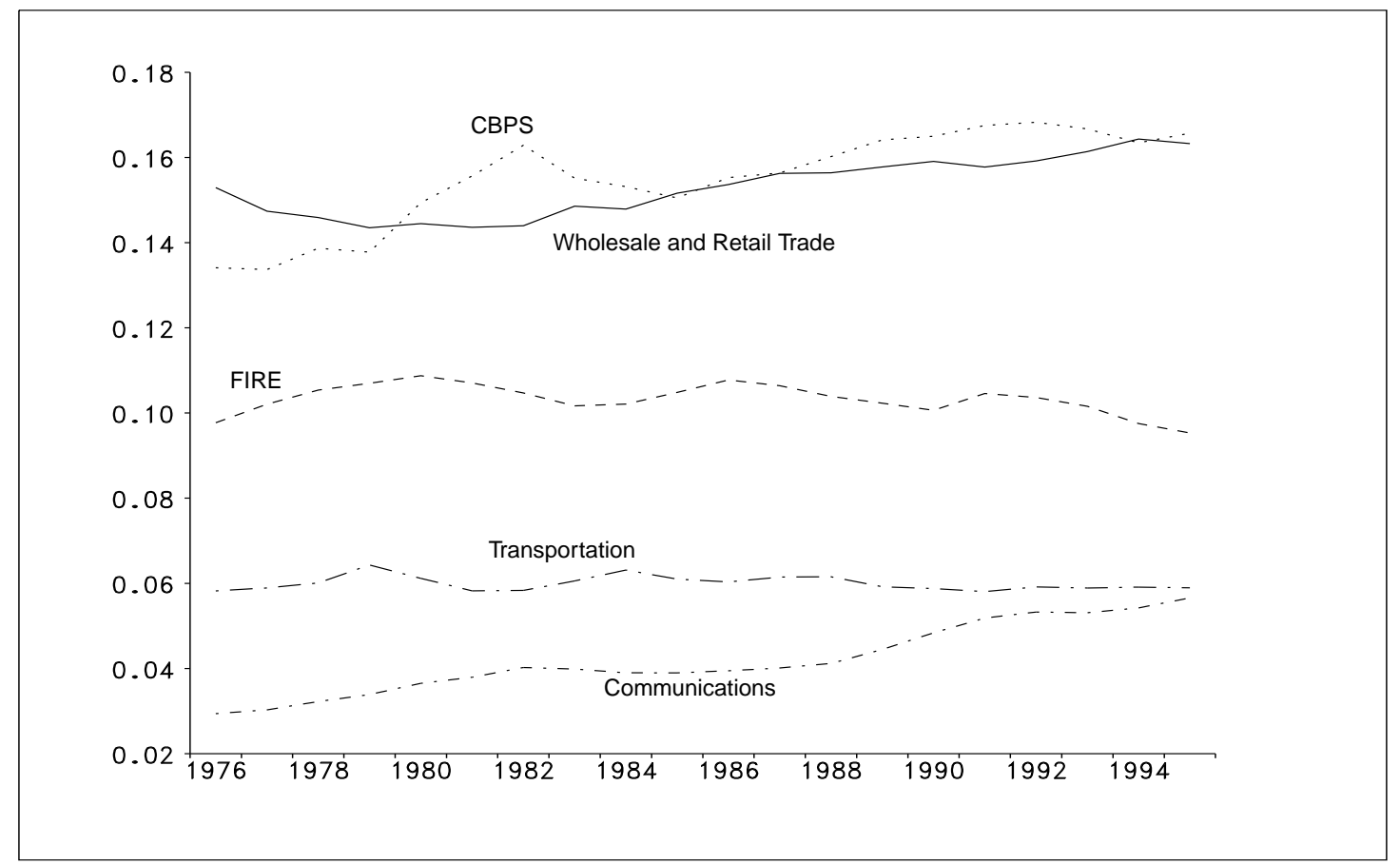

The impact of the increased share of the service sector cannot be fully assessed in a purely accounting fashion, i.e., by looking at productivity growth in expanding sectors compared with declining sectors. For one thing, the alternative scenario is not clear. If output share of the goods sector had not declined, we do not know how strong goodssector productivity growth would have been. Nevertheless, the fact that much of the increased service-sector output has been and will likely continue to be in areas that have shown relatively strong productivity growth or where measurement problems are particularly severe suggests that services will continue to play an important role in increasing potential output and supporting rising real wages. Characterizing the Canadian economy as one where an ever-increasing share of resources is being devoted to low-productivity industries does not appear to be valid. Moreover, because of such factors as technological change and ongoing adjustments to past deregulation, there is considerable potential for greater productivity growth in areas that may have shown slower productivity increases in the past. 


\section{Bibliography}

Acheson, Keith and Stephen Ferris. 1988. Retail and Wholesale Trade Services in Canada. Vancouver: Fraser Institute.

Ayres, R.U. 1991. “Information, Computers, Computer-Integrated-Manufacturing and Productivity." In Technology and Productivity. Paris: OECD, 349-358.

Baily, Martin Neil. 1993. "Competition, Regulation, and Efficiency in Service Industries." Brookings Papers: Microeconomics 2: 71-159.

Baily, Martin Neil and Robert J. Gordon. 1988. "The Productivity Slowdown, Measurement Issues, and the Explosion of Computer Power." Brookings Papers on Economic Activity 2: 347-431.

Baily, Martin Neil and Hans Gersbach. 1995. "Efficiency in Manufacturing and the Need for Global Competition" Brookings Papers: Microeconomics: 307-358.

Bauer, Paul W., Allen N. Berger and David B. Humphrey. 1993. “Efficiency and Productivity Growth in U.S. Banking." In The Measurement of Productive Efficiency, edited by Harold O. Fried, C.A. Knox Lovell and Shelton S. Schmidt. Oxford: Oxford University Press, 386-413.

Baumol, William J. 1967. "Macroeconomics of Unbalanced Growth: The Anatomy of Urban Crisis." American Economic Review Vol. LVII 3 (June):415-426.

Baumol, William J. 1985. "Productivity Policy and the Service Sector." In Managing the Service Economy: Prospects and Problems, edited by Robert P. Inman. New York: Cambridge University Press, 301-317.

Bell, G., F. Chesnais and H. Wienert. 1991. "Highlights of the Proceedings" in Technology and Productivity. Paris: OECD, 7-12.

Chand, U.K. Ranga. 1983. "Growing Service Sector Threatens To Lower Overall Productivity Growth." Canadian Business Review Vol. 10 No. 2:44-47.

Crawford, A. 1993. Measurement Biases in the Canadian CPI. Technical Report No. 64 . Ottawa: Bank of Canada.

David, P.A. 1991. "Computer and Dynamo: The modern productivity paradox in a nottoo-distant mirror." In Technology and Productivity. Paris: OECD, 315-347.

Denison, Edward F. 1973. "The Shift to Services and the Rate of Productivity Change." Survey of Current Business (October):20-35.

Denison, Edward F. 1979. Accounting for Slower Economic Growth: The United States in the 1970s. The Brookings Institution.

Denison, Edward F. 1989. Estimates of Productivity Change by Industry: An Evaluation and an Alternative. Brookings Institution.

Drummond, Don, Mireill Ethier, Maxime Fourgere, Brian Girard and Jeremy Rudin. 1994. "The Underground Economy: Moving the Myth Closer to Reality." Canadian Business Economics Vol. 12 No. 4:3-17. 
Durand, Rene. 1994a. "An Alternative to Double Deflation for Measuring Real Industry Value-Added." Review of Income and Wealth Series 403 (September):303-316.

Durand, Rene. 1994b. “New Alternative Estimates of Real Industry Value-Added for Canada." Draft. Statistics Canada.

Fecher, Fabienne and Pierre Pestieau, 1993, "Efficiency and Competition in O.E.C.D. Financial Services." In The Measurement of Productive Efficiency, edited by Harold O. Fried, C.A. Knox Lovell and Shelton S. Schmidt. Oxford: Oxford University Press, 374-385.

Foss, Murray G., Marilyn E. Manser and Allan H. Young (eds). 1993. Price Measurements and Their Uses. National Bureau of Economic Research, Studies in Income and Wealth 57. Chicago: University of Chicago Press.

Francois, Joseph F. and Kenneth A. Reinert. 1995. The Role of Services in the Structure of Production and Trade: Stylized Facts From a Cross-Country Analysis. Centre for Economic Policy Research, Discussion Paper Series 1228.

Fried, Harold O., C.A. Knox Lovell and Shelton S. Schmidt (eds). 1991. The Measurement of Productive Efficiency. Oxford: Oxford University Press.

Fuchs, Victor R. 1968. The Service Economy. National Bureau of Economic Research.

Griliches, Zvi (ed). 1992. Output Measurement in the Service Sectors. Chicago: University of Chicago Press.

Griliches, Zvi. 1994. "Productivity, R\&D, and the Data Constraint." The American Economic Review (March):1-23.

Griliches, Zvi and Iain Cockburn. 1993. Generics and New Goods in Pharmaceutical Price Indexes. National Bureau of Economic Research, Working Paper No. 4272.

Grossman, Elliot and George Sadler. 1982. "Establishment Data and Productivity Measurements." In What's Happening to American Labor Force and Productivity Measurements? Proceedings of a June 17 Conference Sponsored by The National Council on Employment Policy, 77-108.

Grubel, Herbert G. and Michael A. Walker. 1989. Service Industry Growth. Vancouver: The Fraser Institute.

Hill, T.P. 1977. "On Goods and Services" The Review of Income and Wealth 4 (December):315.

Hogan, John D. (ed.) and Anna M. Craig (assoc. ed). 1980. Dimensions of Productivity Research. Proceedings of the Conference on Productivity Research. The American Productivity Center II.

Kendrick, J.-W. 1991. "Total Factor Productivity - What It Does and Does Not Measure." In Technology and Productivity. Paris: OECD, 149-156.

Leveson, Irving. 1980. "Productivity in Services: Issues for Analysis." In Dimensions of Productivity Research, edited by John D. Hogan and Anna M. Craig. Proceedings of the Conference on Productivity Research. The Amercian Productivity Center II, 765-803. 
Lichtenberg, Frank R. and Zvi Griliches. 1989. “Errors of Measurement in Output Deflators." Journal of Business \& Economic Statistics 7 (January):1-9.

Lowe, Philip. 1995. Labour-Productivity Growth and Relative Wages: 1978-1994. Research Discussion Paper 9505 (September), Reserve Bank of Australia.

McKinsey Global Institute. 1992. Service Sector Productivity. Washington D.C.

McLaughlin, Kenneth J. 1994. "Rigid wages?" Journal of Monetary Economics 34:383-414.

Melvin, James R. 1995. History and Measurement in the Service Sector: A Review. Waterloo Economic Series. Working Paper 9505 (July).

Mirus, Rolf, Roger S. Smith and Vladimir Karoleff. 1994. "Canada's Underground Economy Revisited: Update and Critique." Canadian Public Policy (September):235-252.

Oliner, Stephen D. and William L. Wascher. 1995. "Is a Productivity Revolution Under Way in the United States?" Challenge (November-December):18-34.

Organization for Economic Co-operation and Development. 1991. Technology and Productivity: The Challenge for Economic Policy. Paris: OECD.

Petit, P. 1991. “New Technology and Measurement of Services: The Case of Financial Activities." In Technology and Productivity. Paris: OECD, 207-231.

Roach, Stephen S. 1991. "Services Under Siege - The Restructuring Imperative." Harvard Business Review (September-October):82-91.

Smith, Philip. 1994. "Assessing the Size of the Underground Economy: The Statistics Canada Perspective." Canadian Economic Observer, Statistics Canada Cat. 11-010 (May): 3.16-3.33.

Stuber, Gerald. 1990. "The Goods and Services sectors: A Longer-Term Perspective" Bank of Canada Review (September):14-20.

Trajtenberg, M. 1991. "Quality-Adjusted Price Indices and the Measurement of Economic Growth." Technology and Productivity Paris: OECD, 219-228.

Triplett, Jack E. 1993. “The Measurement of Durable Goods Prices - Book Review.” Journal of Economic Literature XXXI (March):244-245. 


\section{Appendix 1: Calculation of Labour Productivity}

Monthly GDP at factor cost and the Labour Force Survey (LFS) can be used to create measures of productivity by industry and by province that are more disaggregated than those available in the annual productivity estimates. Such estimations, however, are far cruder than the calculation of the annual productivity indexes. For many industries, for example, the employment data are not completely consistent with the output data, since they include persons employed in non-commercial activities. Since such measures are frequently used in research, it is important to assess their accuracy.

The output data used are annual averages of the monthly, industry-based measures of GDP at factor cost. Employment data are from the LFS (total employees by industry) and were obtained from Statistics Canada by special request. Note that contrary to many LFS data sources, the employment numbers used for CBPS do not include non-commercial employment. For some industries, however, employment in non-commercial activities is included. Hours data are calculated by taking annual averages of the monthly series on actual hours worked by industry. These figures are not available at as fine a level of disaggregation as the output and employment data, however.

At the sectoral level, the profile of productivity growth per person given by the in-house calculations is very similar to growth rates calculated using the productivity indexes. The mean rate of growth is similar for commercial goods and commercial services in aggregate (Table 1:1) as are the year-to-year changes. At the industry level, greater differences emerge. (For detailed industry graphs see Figures 1:1 to 1:10.) Within the goods sector, the mean rates of growth are similar for the three industries that can be compared: agriculture, manufacturing and construction. In the case of construction, however, the profile of annual changes is very different. Within the service sector, the differences are generally larger. Mean growth is stronger for the in-house calculations of transportation, FIRE and CBPS and weaker for communications. The annual profiles of productivity change are similar for trade, CBPS, transportation and FIRE. The series for productivity growth in communications, however, look very different. The differences are likely due, at least in part, to inconsistencies between the LFS and output data. Moreover, in the calculation of the productivity indexes, LFS data are supplemented by other sources, such as the Survey of Employment, Payrolls and Hours and industryspecific surveys. 
Table 1:1 Mean Productivity Growth - Comparison with Monthly Series 1977-94

\begin{tabular}{|c|c|c|c|c|}
\hline Industry & $\begin{array}{c}\text { Output/ } \\
\text { person-hour } \\
\text { (calculated) }\end{array}$ & $\begin{array}{c}\text { Output/ } \\
\text { person } \\
\text { (calculated) }\end{array}$ & $\begin{array}{l}\text { Output/ } \\
\text { person-hour } \\
\text { (index) }\end{array}$ & $\begin{array}{l}\text { Output/ } \\
\text { person } \\
\text { (index) }\end{array}$ \\
\hline Goods & - & 1.8 & 1.9 & 1.8 \\
\hline Agriculture & 2.4 & 1.8 & 2.2 & 1.4 \\
\hline Mining, quarrying, oil & 1.2 & 1.7 & - & - \\
\hline Manufacturing & 1.8 & 2.1 & 2.0 & 2.1 \\
\hline Construction & 0.7 & 0.7 & 0.9 & 0.8 \\
\hline Fishing and trapping & \multirow{2}{*}{1.8} & -0.6 & - & - \\
\hline Logging and forestry & & 1.9 & - & - \\
\hline Utilities & - & 1.8 & - & - \\
\hline Services & - & 0.8 & 0.9 & 0.6 \\
\hline $\begin{array}{l}\text { Transportation and } \\
\text { storage }\end{array}$ & \multirow[t]{2}{*}{$2.8^{\mathrm{a}}$} & 2.6 & 1.6 & 1.8 \\
\hline Communications & & 4.4 & 5.8 & 5.7 \\
\hline $\begin{array}{l}\text { Community, business } \\
\text { and personal services }\end{array}$ & $-0.4^{\mathrm{b}}$ & -0.6 & -0.4 & -0.8 \\
\hline Retail trade & \multirow{2}{*}{1.3} & 0.1 & 0.8 & 2.0 \\
\hline Wholesale trade & & 2.9 & 1.9 & 0.4 \\
\hline $\begin{array}{l}\text { Finance, insurance } \\
\text { and real estate }\end{array}$ & 0.2 & 0.2 & 0.4 & -0.2 \\
\hline
\end{tabular}

a. Also includes utilities

b. Average hours for CBPS includes non-commercial elements. 
Figure 1:1 Goods

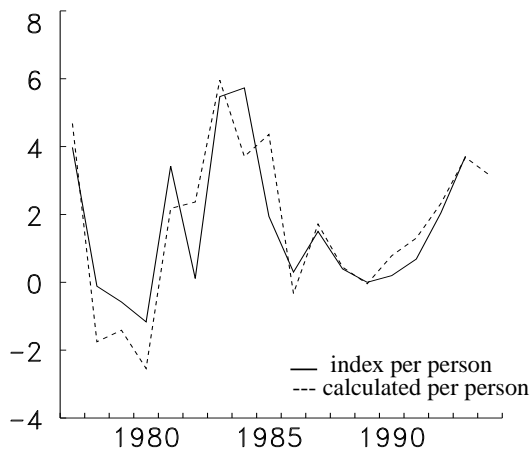

Figure 1:4 Construction

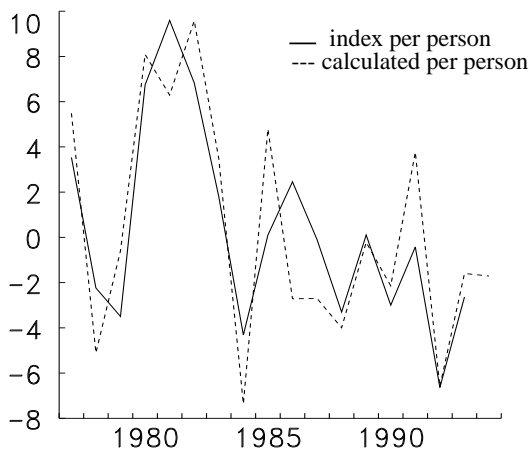

Figure 1:2 Agriculture

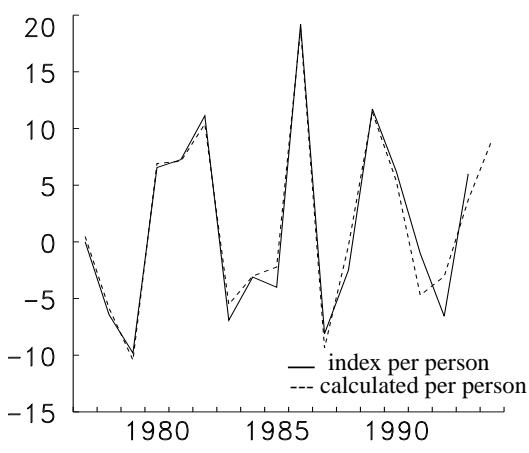

Figure 1:5 Services
Figure 1:3 Manufacturing

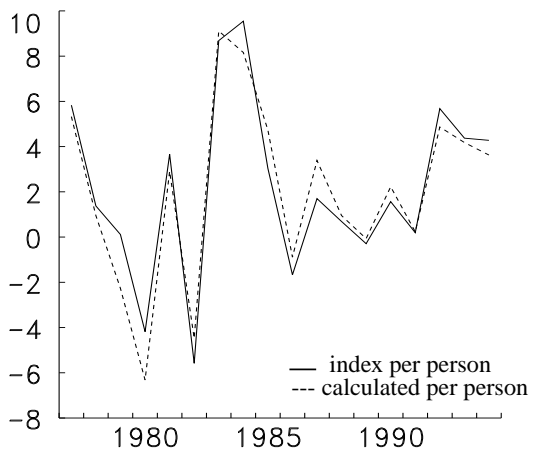

Figure 1:6 Transportation
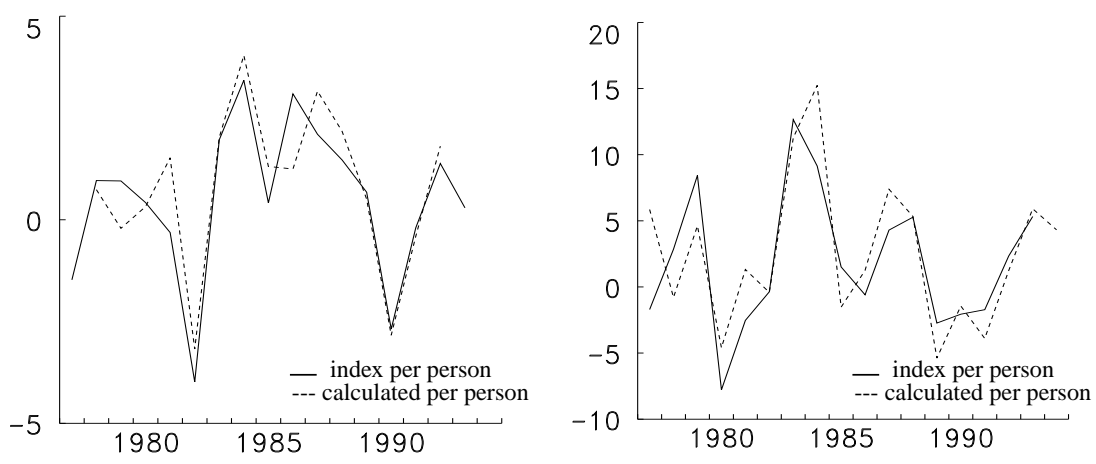

Figure 1:7 Communications

Figure 1:8 Trade
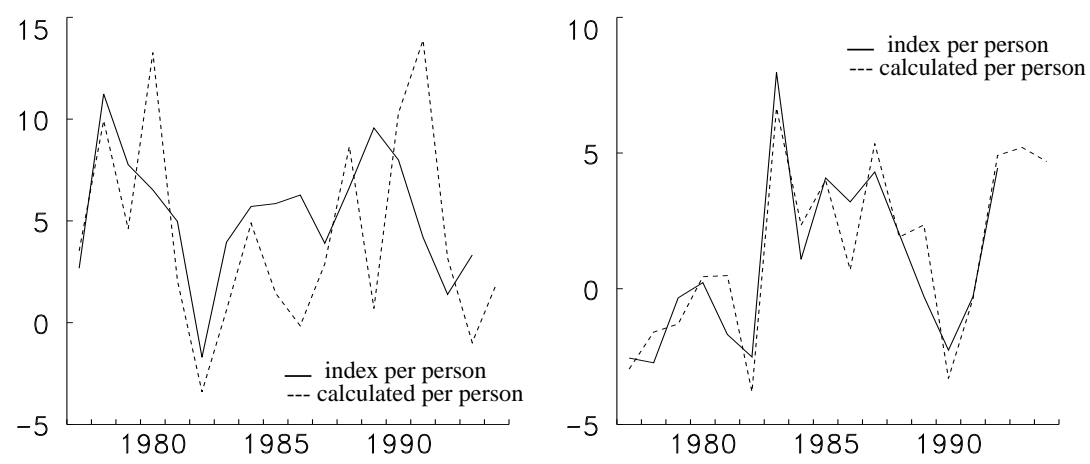

Figure 1:9 FIRE

Figure 1:10 CBPS
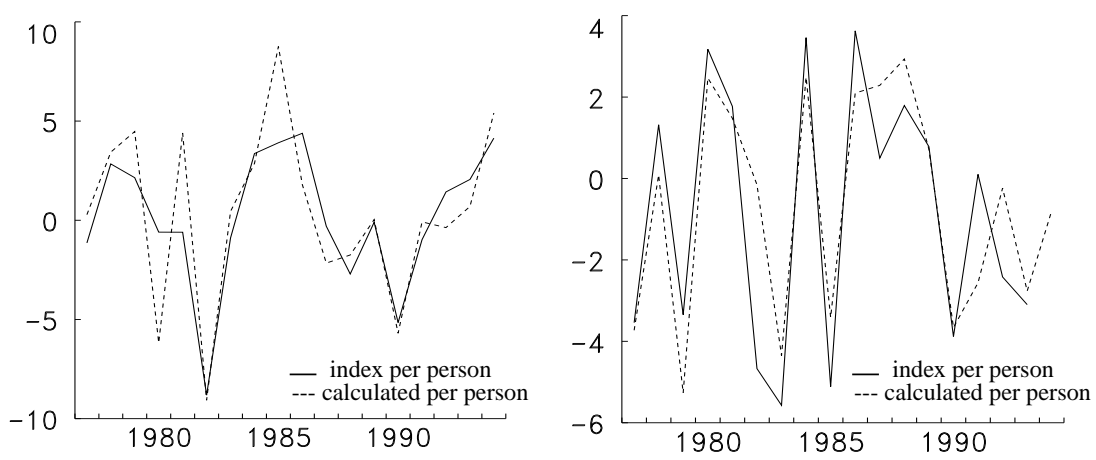


\section{Appendix 2: The Measurement of FIRE, CBPS and Trade}

\section{FIRE}

The first major component of FIRE is banks and other deposit-taking financial institutions. For these, Statistics Canada calculates nominal output as the sum of: imputed service charges, receipts from services for which a specific service charge is made, and other revenue such as rent.

The imputed value of service charges is calculated as the difference between interest received and interest paid. ${ }^{27}$ The value of interest payments received from loans and paid out on deposits is first deflated by the total CPI. It is then adjusted for changes in the "service margin" or the "intermediation rate"; that is, the difference between interest rates for loans and deposits. (This can also be thought of as the unit price of a dollar loan/receipt.) This margin is calculated for the base year and then applied to the deflated value of loans and deposits. Thus, changes in the margin are treated as price changes and are not reflected in movements in real output.

Detailed data are not available on the components of the explicit service charges made by banks. Published rates on certain standardized services (for example, processing cheques) are used, along with CPI and wage information, to create overall deflators. It is very hard, however, to disentangle price and quantity changes in this area. Charges such as credit card fees and ABM fees are not shown separately.

There are three main exceptions to this characterization of output for banks and depositaccepting institutions: trust/deposit-accepting mortgage companies, credit unions and the Bank of Canada.

In the case of trust/deposit-accepting mortgage companies, the non-explicit service charges are imputed only for loans and deposits to and from the personal sector. Business sector or government transactions are not included. In other words, it is assumed that they do not use such services. This means that GDP for the trust/depositaccepting mortgage companies is understated by the amount of business and government sector activity.

For both the Bank of Canada and credit unions, output is equal to operating expenses. In the case of the Bank of Canada, interest earned comes mainly from the return on government of Canada securities and is therefore treated as a transfer from government. For credit unions, since they are membership organizations, interest paid is treated as part of operating profits; profits are distributed to members through bonus interest, interest rebates and dividends. In both cases, therefore, output is equal to inputs, and productivity growth is assumed to be zero. (Note, however, that Statistics Canada proposes to alter the methodology for credit unions by using a measure of output similar to that of trust companies.)

27. Note that this differs considerably from other industries, where interest and dividends are considered to be paid out of the surplus. They are thus included in the output of the industry paying them and considered as a transfer (and therefore not part of operating revenue) for the industries receiving such transfers. In the case of banks, however, interest received is a very large component of total receipts, and deducting it from the total would produce very low or negative output. 
The next major component of FIRE is "other finance and real estate," which includes credit agencies, security dealers, investment companies and real estate operators. The output of firms within this component can be broadly characterized as the sum of sales of goods and services, rental income, commissions, royalty income and other operating income.

- The output of credit agencies also includes the administrative cost of consumer credit and depreciation incurred on equipment rented under capital lease arrangements. Consumer loans are not currently deflated in the same way as bank loans, though this will likely be done in the future. Currently the deflator is based on the general CPI and wages of employees.

- The output of security dealers includes security trading profits.

- The major outputs of investment companies and other financial agencies are sales of services such as mutual funds, stock and bond commissions, royalty income and real estate rent. Two main deflators are used for investment dealers. Commissions from underwriting are deflated by the CPI, then adjusted by the margin earned on a $\$ 1$ issue of a specific bond type in the base year. Commissions on securities trading are deflated by base-year commissions and the price of stock as given by the stock exchange index.

- For real estate operators and lessors and real estate developers, the major outputs are real estate rent and commissions. Residential rents are reduced by "facility expenses," which refers to the operating expenses of the residence, including depreciation of furniture and appliances, the cost of utilities, and the cost of cable television. The deflator for real estate commissions is based on MLS data on the price of retail housing traded, other data on average house prices, and incomes earned by real estate brokers.

The unincorporated component includes: paid farm rent (residential and nonresidential), non-farm paid rent (residential and commercial), royalties received by persons, rent of appliances provided by the landlord, trusteed pension funds, government mortgage enterprises, insurance and real estate agencies, and mortgage insurance funds.

All residential rent income is deflated by the rent component of the CPI. The deflator for commercial rent is based on published data on rents per square foot by class of building. A moving average of three to five years is used, reflecting the average length of rent contracts.

The final category is insurance. There are three main kinds of insurance: life insurance, property and casualty insurance, and medical insurance. For life insurance companies, output is calculated as the sum of: intermediate expenses, employee compensation, dividends paid to shareholders, depreciation, and an estimate of gross rental income. Like credit unions, life insurance companies are treated as though they were owned by individuals, and output is largely equated with inputs. For property and casualty insurers, output equals the difference between insurance premiums earned and claims paid out, plus an estimate of gross rental income. For the real measure, premium income is deflated by the relevant CPI component (for example, auto insurance premiums) and multiplied by the "service margin," which is the ratio of claims to premiums paid in the 
base year. In the case of private medical insurance plans, output is equal to intermediate expenses.

\section{Community, Business and Personal Services}

\section{Health and Education Services (commercial sector only)}

For education, real output is calculated by deflating gross receipts by price indexes that are based on the cost of inputs for public sector education. Non-institutional expenditures are derived from data drawn from the Family Expenditure Survey on average family expenditures on private lessons and courses.

For physicians, dentists, medical laboratories and paramedical practitioners (optometrists, chiropractors, physiotherapists etc.), output is also based on gross receipts, deflated by the CPI.

Output of hospitals and nursing homes is based on operating expenditures and the deflators combine CPI information and public sector costs. Data on expenditures for private hospitals and nursing homes are estimated using the number of patient-days in private hospitals multiplied by the cost per patient-day in public hospitals. Adjustments are also made to take account of higher operating costs and profits in the private sector. The detail of commodity expenditures is also based on that of public hospitals.

\section{Business Services}

For all business services, output is calculated by deflating gross revenues.

The biggest single component of business services is computer and related services, which includes software services, rental of data-processing equipment, repair services and gross margins on goods purchased for resale. Much of the data are available from annual surveys and Revenue Canada tax information. The deflators are currently based on survey information of the costs of different software.

The miscellaneous business services category covers such things as employment agencies, credit bureaus, telephone answering services, and management consultants. Growth in revenues for this industry are based on movements in wages and salaries.

Professional business services include accountants, lawyers, architects and engineering services. Data are often very scarce for these services. In the case of engineering services, deflators are based on data from a survey of consulting engineers. For architectural services, the deflator is partly based on the engineering price index and partly on average weekly earnings. For accountants, average weekly earnings are also used as a deflator. For legal services, the deflator is based on the volume of cases and labour data. Advertising services involving printed matter are deflated using an index based on the advertising rates of a sample of newspapers. For radio and television, the deflators are based on audience/viewing hours. (The more people listening/watching, the lower the price.)

\section{Personal Services}

The accommodation and food services industry produce the commodities, accommodation and meals with service margins on alcoholic beverages. Deflators are 
based on CPI components.

Under recreational services, gross revenues from motion picture production and motion picture exhibition are both deflated by the CPI component for motion picture exhibitions. The output of lotteries is based on ticket sales and the output of race track operations on net gate receipts.

Other personal services include: laundries and cleaners, barber and beauty shops, funeral services, shoe repair shops, private daycare, and child care outside the home. Data on childcare is based on the number of spaces in child care centres and the average cost per child. Deflators for these services are generally based on the CPI.

The deflator for auto and truck rentals is based on the CPI. For machinery and equipment rentals, a price index for total domestic machinery and equipment is used.

\section{Retail and Wholesale Trade}

Statistics Canada's measurement of real GDP in the trade industry is done on a different basis from most other industries. Output is based on value-added or trade margins, i.e., the difference between the value of sales and the cost of the goods purchased for resale. To calculate real output for wholesale trade, ratios of the gross wholesale margin to the producer price value of the good are calculated for each commodity for the base year and the current year, and an average of the two is calculated. This average margin is then applied to the constant dollar producer value of the good. A similar method is used for retail trade, except that the gross retail margin is calculated as a ratio of the addition of the producer price value, the wholesale margin and the transportation margin. Similarly, the average real retail margin is multiplied by the sum of the deflated producer value of the good, the deflated wholesale margin and the deflated transportation margin.

Evidently, the real trade margin is not a direct measure of what purchasers would generally describe as the output of a trader. Similarly, there is no deflator applied to distinguish between pure price and quality changes. In particular, characteristics such as convenience and waiting times, which are important to the customer, are not measured in any way. Rather, as a result of the averaging method used, any changes in the gross margin are split equally between price changes and a change in real output. As well, as noted earlier, data coverage is less complete in trade than in most industries. 


\section{Bank of Canada Working Papers}

1997

97-1 Reconsidering Cointegration in International Finance:

Three Case Studies of Size Distortion in Finite Samples

M.-J. Godbout and S. van Norden

97-2 Fads or Bubbles?

H. Schaller and S. van Norden

97-3 La courbe de Phillips au Canada: un examen de quelques hypothèses

J.-F. Fillion and A. Léonard

97-4 The Liquidity Trap: Evidence from Japan

I. Weberpals

97-5 A Comparison of Alternative Methodologies for

Estimating Potential Output and the Output Gap

C. Dupasquier, A. Guay

and P. St-Amant

97-6 Lagging Productivity Growth in the Service Sector:

Mismeasurement, Mismanagement or Misinformation?

D. Maclean

1996

96-5 A Distant-Early-Warning Model of Inflation Based on M1 Disequilibria

J. Armour, J. Atta-Mensah, W. Engert and S. Hendry

96-6 Provincial Credit Ratings in Canada: An Ordered Probit Analysis

S. Cheung

96-7 An Econometric Examination of the Trend Unemployment Rate in Canada

D. Côté and D. Hostland

$96-8$

Interpreting Money-Supply and Interest-Rate Shocks as Monetary-Policy Shocks

M. Kasumovich

96-9 Does Inflation Uncertainty Vary with the Level of Inflation?

A. Crawford and M. Kasumovich

96-10 Unit-Root Tests and Excess Returns

M.-J. Godbout and S. van Norden

96-11 Avoiding the Pitfalls: Can Regime-Switching Tests Detect Bubbles?

S. van Norden and R. Vigfusson

96-12 The Commodity-Price Cycle and Regional Economic Performance in Canada

M. Lefebvre and S. Poloz

96-13 Speculative Behaviour, Regime-Switching and Stock Market Crashes

S. van Norden and H. Schaller

96-14 L'endettement du Canada et ses effets sur les taux d'intérêt réels de long terme

J.-F. Fillion

96-15 A Modified P*-Model of Inflation Based on M1

J. Atta-Mensah

Earlier papers not listed here are also available.

Single copies of Bank of Canada papers may be obtained from

Publications Distribution, Bank of Canada, 234 Wellington Street Ottawa, Ontario K1A 0G9

E-mail: publications@bank-banque-canada.ca

WWW: http://www.bank-banque-canada.ca/

FTP: $\quad$ ftp.bank-banque-canada.ca (login: anonymous, to subdirectory

/pub/publications/working.papers/) 